Temporary relief of pain at the time of treatment was recorded in $92 \%$ of the patients receiving traction and $86 \%$ of those who were positioned without traction.

The rate of improvement was approximately the same in the five treatment groups, as judged by clinical assessment two weeks and four weeks after the beginning of treatment and by followup questionary at six weeks and six months.

The improvement at four weeks was influenced by age, the initial severity of symptoms, the number of previous attacks, the duration of previous attacks, and whether the patient was getting better or worse when first seen.

We are deeply indebted to all the patients, doctors, physiotherapists, secretaries, and administrative staff who helped with this trial. Dr. D. J. Newell and his staff did invaluable work in analysing the statistics. Dr. P. J. R. Nichols was responsible for organizing and co-ordinating the returns from each centre.
We gratefully acknowledge the gift of $£ 1,200$ from the National Fund for Research into Poliomyelitis and other Crippling Diseases, which made this trial possible.

The Arthritis and Rheumatism Council Field Unit helped considerably by providing figures from studies on the $x$-ray changes in the general population of Leigh and Wensleydale.

\section{REFERENCES}

Epidemiology of Chronic Rheumatism 1963, vol. 2, edited by J. H. Kellgren, M. R. Jeffrey, and J. Ball. Blackwell, Oxford.

Lawrence, J. S. (1963). Epidemiology of Chronic Rheumatism, edited by J. H. Kellgren, M. R. Jeffrey, and J. Ball, vol. 1, p. 100. Blackwell, Oxford.

- (1965), Personal communication.

Lishman, W. A., and Ritchie Russell, W. (1961). Lancet, 2, 941.

Medical Research Council (1964). Report for 1962-3, pp. 21-25. H.M.S.O., London.

Steinberg, V. L., and Mason, R. M. (1959). Ann. phys. Med., 5, 37

Wareham, T., and Farrow, R. (1960). Lancet, 2, 336

\title{
Leukaemia and Neoplastic Processes Treated with Langat and Kyasanur Forest Disease Viruses : a Clinical and Laboratory Study of 28 Patients
}

\author{
H. E. WEBB, * D.M., M.R.C.P. ; G. WETHERLEY-MEIN, $\dagger$ M.D., M.R.C.P. \\ C. E. GORDON SMITH, $\ddagger$ M.D., M.R.C.P. ; DOLORES MCMAHON,§ B.SC.
}

Brit. med. F., 1966, 1, 258-266

Marked leucopenia occurs both in naturally occurring Kyasanur Forest disease (Chatterjea et al., 1963) and in Macaca radiata monkeys experimentally infected with Kyasanur Forest disease (Webb and Chatterjea, 1962). The large amounts of nuclear debris seen phagocytosed in the reticulo-endothelial system following the leucopenia suggested that leucocytes are destroyed by the virus (Webb and Chatterjea, 1962 ; Webb and Burston, 1966), that Kyasanur Forest disease virus or the closely related Langat virus might be used to treat leukaemic patients, and that there might be an oncolytic effect on other neoplastic conditions. Both viruses are members of the closely related tickborne complex of group B arthropod-borne arboviruses.

Langat virus, which was isolated from the tick Ixodes granulatus in Malaya (Smith, 1956), was mainly used in this study. Human infections with it are rare and no natural disease due to it is known. It was hoped that Langat virus might produce at least a remission in some of the patients with little or no virus-induced illness. If the infections caused only mild symptoms or were asymptomatic this virus would be a candidate live vaccine against the serious illnesses produced by other tick-borne complex viruses. Experiments in monkeys (O'Reilly et al., 1965) have shown that considerable crossprotection can be conferred by a similar strain and passage level of Langat virus against other tick-borne complex viruses (Kyasanur Forest disease, tick-borne encephalitis). Price et al. (1961) showed that one strain of Langat virus (TP-21-9) which had been passaged in chick-embryo-tissue cultures did not

* Consultant Neurologist and Senior Lecturer, St. Thomas's Hospital and Medical School, London.

t Professu: of Haematology, St. Thomas's Hospital and Medical School,

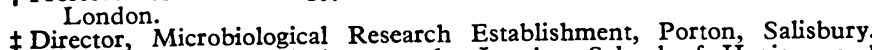
Late Reader in Virology at the London School of Hygiene and Tropical Medicine.

5 Senior Scientific Officer, Microbiological Research Establishment, Porton, Salisbury. Late of the London School of Hygiene and Porton, Salisbury.

Tropical Medicine.
Much of the work by two of us (C. E. G. S. and D. McM.) was done at the London School of Hygiene and Tropical Medicine. produce encephalitis when inoculated intracerebrally into rhesus monkeys and that when three live viruses-yellow fever, West Nile, and Langat (TP-21-9)-were given in series there was subsequent good protection against a wide range of group B arboviruses. Shah et al. (1962) studied Langat virus in mice and guinea-pigs and demonstrated a good measure of protection against some tick-borne complex viruses. Smorodintsev (1963) carried out preliminary trials in man with live Langat virus as a vaccine against Russian spring-summer encephalitis.

Virus was therefore given to patients with various malignant diseases. Most patients were in the late stages of the disorder, many had become refractory to conventional therapy, and the remainder were thought unlikely to respond to such treatment. The nature of the treatment was carefully explained to each of them and to their relatives by one of us and their full consent was obtained.

\section{Materials and Methods}

Since November 196033 patients have been treated. The 28 whose findings are presented fall into two main groups: 10 leukaemic patients and 18 with a variety of other neoplastic processes, of which bronchial carcinoma was the most common (Tables I and II). The remaining five patients given virus are mentioned only briefly: three given virus orally developed neither viraemia nor antibodies; one died following a myocardial infarction 48 hours after inoculation and no virus was recovered post mortem ; one died three hours after inoculation, from respiratory failure, and virus was recovered from the site of inoculation only.

All but one of the patients with leukaemia were receiving, or had been receiving, singly or in combination, chlorambucil, mercaptopurine, and prednisone. Though these drugs could have influenced the course of the virus infection and the development of antibodies they could not have been directly responsible for any observed therapeutic or haematological 
effects, since, with the exception of Case 8, virus was given only when there was convincing evidence that the drugs were ineffective. All the patients were kept in hospital for at least 28 days or until death.

\section{Virology}

Viruses.-Patients were infected with bacteriologically sterile mouse-brain virus diluted in sterile saline containing $0.75 \%$ bovine albumin and buffered at $p \mathrm{H} 7$. When the patient was inoculated the virus was simultaneously titrated by intracerebral inoculation of mice 3-4 weeks old. All infectivity titres were calculated by moving averages (Thompson, 1947). Langat virus (TP-21 strain) was used in its seventh mouse-passage. Four patients were given the TP-77 strain of Langat. Kyasanur Forest disease virus (W3771 CD IV strain) was used in its seventh or eighth mouse-passages.

Viraemia and Post-mortem Tissues.-After inoculation blood was taken three times a week for the likely duration of viraemia. Several ampoules of each sample were stored at $-70^{\circ} \mathrm{C}$. Sera were stored at $-20^{\circ} \mathrm{C}$. until tested. The blood samples were later inoculated intracerebrally $(0.02 \mathrm{ml}$.) into baby mice (1-4 days old). If symptoms or death occurred within 21 days an extract of their brains was tested by complement-fixation against homologous antiserum. If the presence of virus was confirmed in baby mice (after passage, if necessary) another ampoule of blood was titrated in mice 3-4 weeks old. Post-mortem tissues were ground up and centrifuged, and the supernatant was similarly dealt with.

\section{Serology}

(a) Haemagglutinin-inhibition Tests.-These were carried out as described by O'Reilly et al. (1965) at a sedimentation $\mathrm{pH}$ of 6.5. All sera from a single patient were tested in the same test.

(b) Neutralization Tests.-These were carried out as described by Smith et al. (1962), with a one-hour incubation period for the serum-virus mixtures. The mice were observed for 14 days. All sera from a single patient were, so far as was possible, tested in the same test.

(c) Complement-fixation Tests.-(1) Inactivated sera diluted $1: 5$ were subjected to a Fulton and Dumbell (1949) test against an excess of antigen and $0.2 \mathrm{log}$ dilutions of complement. (2) Dilutions of inactivated sera were tested against $2 \frac{1}{2}$ units of complement and an optimal amount of antigen previously determined in a Fulton and Dumbell test: these tests were carried out with Microtiter equipment (Cooke Eng. Co., Alexandria, Virginia) with $0.025 \mathrm{ml}$. unit volumes (Sever, 1962). Antigen was prepared by centrifugation at 3,000 r.p.m. for 10 minutes of a $20 \%$ suspension of infected suckling-mouse brain in $0.75 \%$ bovine albumin buffered at $p \mathrm{H} 9$. All sera from a single patient were tested in the same test.

\section{Other Investigations}

With the use of standard techniques the following data were obtained before and after virus-inoculation: haemoglobin level, total white blood count and differential leucocyte count, platelet count, erythrocyte sedimentation rate, plasma protein level (including electrophoresis), and, in some cases, cells and protein in cerebrospinal fluid (C.S.F.), electroencephalogram (E.E.G.), and electrocardiogram (E.C.G.).

Total leucocyte counts were carried out in duplicate with a standard error of $\pm 5 \%$, and differential leucocyte counts were recorded by two independent observers.

Blood and bone-marrow films were stained by Leishman's method. Biopsy and necropsy tissues, fixed in buffered formalin and paraffin-embedded, were stained by standard techniques.

Direct marrow-chromosome preparations were obtained by a modification of the method of Moorhead et al. (1960).

\section{Results}

\section{Clinical Effects of the Virus}

Some patients, afebrile at the time of inoculation, developed transient fever between the $3 \mathrm{rd}$ and 15 th post-inoculation days. Only two patients showed subjective or objective evidence of virus infection: Cases 5 and 8 developed clinical encephalitis, which was confirmed at necropsy (Burston et al., 1966).

Case 5.-A man aged 37 was diagnosed as suffering from erythroleukaemia in May 1960. Treatment with blood transfusion, mercaptopurine, and corticosteroids gave partial control and enabled him to work until December 1961, when his condition deteriorated clinically and haematologically and was refractory to treatment. In March 1962 (Hb 9.8 g./100 ml.; W.B.C. 26,900/c.mm. (undifferentiated blast cells $61 \%$ ); platelets $6,000 / \mathrm{c} . \mathrm{mm}$.) he was given Langat virus: the total leucocyte count fell to $45 \%$ of the pre-inoculation level by the eighteenth post-inoculation day but there was no clinical improvement. On the twenty-third day he developed a neurological disturbance affecting the brain-stem. The C.S.F. contained 35 immature mononuclear cells per c.mm. and $45 \mathrm{mg}$. of protein per $100 \mathrm{ml}$. He recovered from these symptoms within a week but died of pneumonia on the forty-fourth day. There was histological evidence of a diffuse non-suppurative encephalitis.

Case 8.-A woman aged 70 presented in January 1962 with anaemia and considerable thrombocytopenic bleeding, diagnosed as chronic lymphocytic leukaemia (Hb 7.2 g./100 ml.; W.B.C. $382,000 /$ c.mm. (98\% lymphocytes); platelets $9,000 /$ c.mm.). In spite of blood transfusion, chlorambucil, and corticosteroids deterioration was progressive. In February 1962 chlorambucil was stopped and she was given Langat virus. The leucocyte count fell to $60 \%$ of the pre-inoculation level by the seventh day after inoculation (possibly a chlorambucil effect) but there was no clinical improvement. On the twenty-fourth day she developed ptosis, gross nystagmus, and became drowsy and confused. A lumbar puncture failed and she died on the twenty-ninth day. C.S.F. taken shortly after death contained 150 cells per c.mm. (95\% mononuclear), protein $200 \mathrm{mg} . / 100 \mathrm{ml}$., with no excess globulin. Histology showed a non-suppurative encephalomyelitis.

\section{Therapeutic Effects}

A number of patients showed haematological, histological, and chromosomal changes which could be regarded as virus effects. Such of these changes as were not clearly associated with any convincing therapeutic effect are considered later. In terms of therapeutic effect the patients fell into four groups -those showing unequivocal clinical improvement, those in whom there was doubtful improvement, those in whom the effect was adverse, and those in whom the disease process appeared to be completely unmodified.

\section{Definite Benefit}

There were four patients in this group-two with leukaemia and two with carcinoma.

Case 6.-A woman aged 55 presented with typical chronic myeloid leukaemia in August 1955. This was satisfactorily controlled with busulphan until March 1960, when there was a gradual transition to a clinically acute blast-cell process. For 10 months this was partially controlled by varying combinations of mercaptopurine, prednisone, and blood transfusion. In January 1961 there was a rapid clinical deterioration with a rising blast-cell count and falling platelets and haemoglobin (Fig. 1). She was ill, bruised easily, and had generalized lymph-node enlargement and an enlarging spleen extending $14 \mathrm{~cm}$. below the costal margin. She was inoculated with Langat virus, and in the 13 days after inoculation the lymph nodes and spleen became much smaller, the leucocyte count fell from 310,000 to $10,400 / \mathrm{c} . \mathrm{mm}$. (Figs. 1 and 2 ), and there was subjective 
improvement. These effects were transient, and she died with a staphylococcal septicaemia and an associated aspergillosis on the twenty-fifth day.
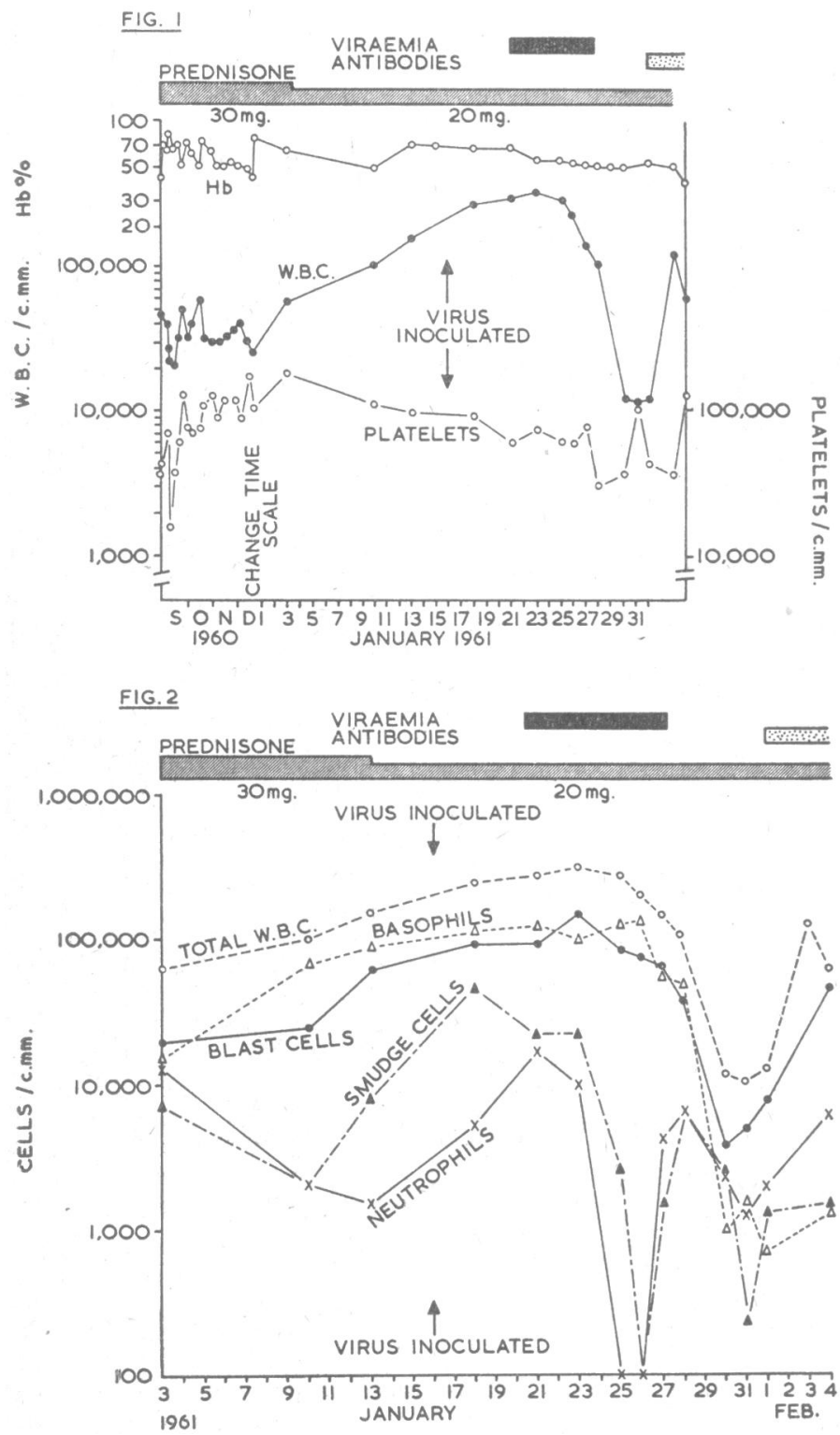

Fig. 1.-Case 6. Haematological findings before and after inoculation FIG. 1.- Case 6. Haematological findings before and after inoculation of virus (Langat) in a patient with blast-cell transition of chronic granulocytic leukaemia. Haemoglobin level is expressed as \% Haldane. FIG.
after inoculation of virus (Langat).

Case 3.-A woman aged 67 with acute blast-cell leukaemia presented in May 1962 with a two-weeks history of malaise, purpura, and generalized ulcerating leukaemic skin lesions ( $\mathrm{Hb} 8.8 \mathrm{g./}$ $100 \mathrm{ml}$. ; W.B.C. 24,000/c.mm (undifferentiated blast cells $80 \%$ ); platelets $67,000 /$ c.mm.). Spleen and lymph nodes were impalpable. Five days after diagnosis she was inoculated with Kyasanur Forest disease virus. She received no other treatment, and after the ninth post-inoculation day the ulcerating skin lesions dried, the scabs separating and finally leaving dry healing epithelium. This was associated with a fall in leucocyte count from $58,000 / \mathrm{c} . \mathrm{mm}$. on the fourth day to 4,800 on the fifteenth day (Fig. 3). During this period her fever settled and there was some subjective improvement. She died suddenly on the sixteenth day with bilateral massive suprarenal haemorrhages.

Case 21.-A woman of 59 was admitted in December 1963 with ascites and gross hepatomegaly. Laparotomy showed multiple metastatic deposits of squamous-cell carcinoma in the liver. The primary site was not identified. Two visible and palpable secondary deposits appeared in the skull vault, causing destruction of the anderlying bone. She was given Langat virus, and between the seventh and twenty-first days there was apparently complete regression of the skull secondaries. This was associated with a reduced rate of reaccumulation of the ascites and some subjective improvement. After three weeks there was further clinical deterioration but no regeneration of the secondary skull nodules. She died at home three and a half months later. There was no necropsy.

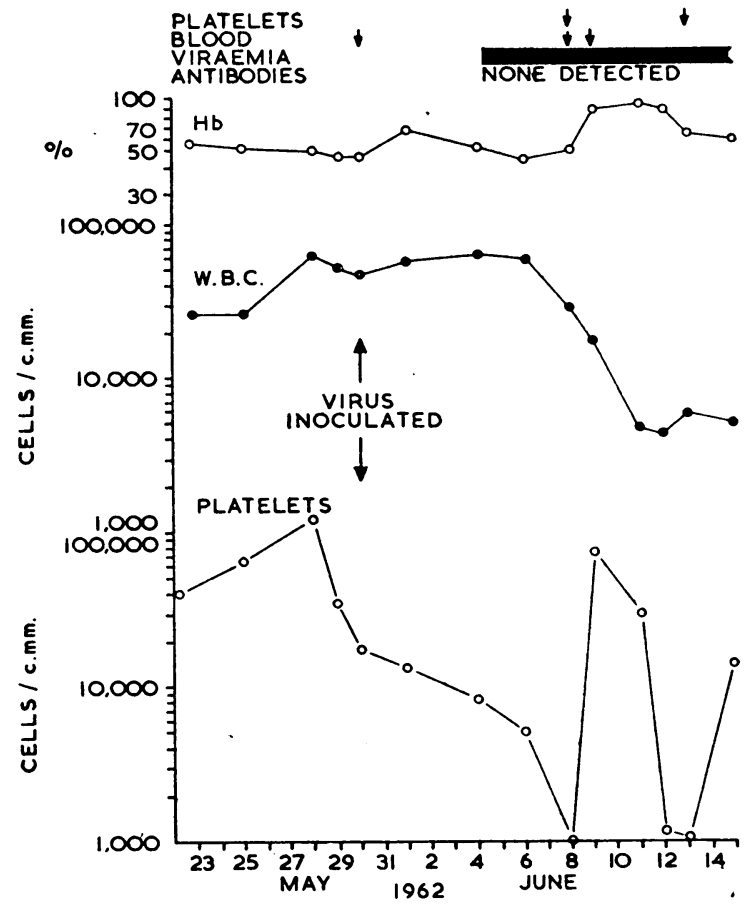

FIG. 3.-Case 3. Haematological findings before and after inoculation of Kyasanur Forest disease virus in a patient with acute blast-cell leukaemia. Haemoglobin level is expressed as $\%$ Haldane. Arrows at top indicate days transfusion of blood and platelets were given.

Case 12.-A man aged 59 had carcinoma of the bronchus confirmed by biopsy. He was first treated with Langat virus and radiotherapy in July 1961 . The combined therapy made assessment of the role of virus in the subsequent improvement impossible. Perhaps because of the radiotherapy, his antibody response to the virus was, in spite of some viraemia, poor and transient. Therefore, when four months later there was such clinical deterioration that his condition was regarded as terminal, he was inoculated with Kyasanur Forest disease virus. From the third to the eleventh day he was febrile, and by the twenty-sixth day his clinical improvement was so striking that he was ambulant and cheerful. By the fortieth day there was further deterioration; he died of bronchopneumonia on the fifty-fifth day. At necropsy there was no macroscopic or microscopical evidence of tumour in the lung. Tumour was present in liver and adrenal and there was active pyelonephritis.

\section{Doubtful Benefit}

In three patients it was difficult to attribute to the virus the improvement which followed therapy, either because of other simultaneous treatment or because of the variable nature of the disease itself.

Case 20.-A man of 54 was admitted in April 1961 with a sixweeks history of unsteadiness and a tendency to fall to the right. He was grossly ataxic and almost blind from papilloedema. A biopsy was made of a cerebellar tumour, which was partially removed. The primary carcinoma in the lung was discovered a few days later. Sixteen days after the biopsy he was given Langat virus. There was remarkable clinical improvement and he was back at work in three months. During this time he put on $38 \mathrm{lb} .(17.2 \mathrm{~kg}$.) in weight. He remained working for a further three months and then deteriorated. How much of the improvement was due to partial excision of the secondary and how much to virus therapy cannot be determined. When he relapsed he was given Kyasanur Forest disease virus with no beneficial or detrimental effect. He died eight months after the original virus inoculation. 
Case 28.-A man aged 41 presented in June 1963 with a solitary myeloma of the sternum, which was treated with radiotherapy. Within six months bone pain returned and $x$-ray examination showed generalized skeletal deposits of myeloma. He developed severe pain in his thoracic cage, thrombophlebitis of the legs, and pneumonia. After inoculation with Langat virus he gained weight, the pain became much less, his E.S.R. fell, and he returned to work. There was no convincing radiological bone change. Fifteen months after being given virus he had a recurrence of pain in his back and ribs. For this he was given a course of melphalan with benefit, and has continued with this as intermittent therapy. He remained reasonably well two years later.

Case 18.-A man of 59 was admitted in April 1964 complaining of having had severe pain in the left shoulder, right loin, and right leg for eight weeks. There were many skin nodules. Biopsies established the diagnosis of oat-cell carcinoma of the bronchus with multiple skin secondaries. He was given Langat virus and ran a mild pyrexia of $99.4-100^{\circ} \mathrm{F}$. $\left(37.4-37.8^{\circ} \mathrm{C}\right.$.) between the fourth and thirteenth post-inoculation days. No regression of skin nodules resulted, but there was a most striking improvement in his pain. He died on the twenty-sixth day, and necropsy showed very extensive metastatic spread of tumour.

\section{Adverse Effect}

Case 13.-A man aged 60 was admitted in September 1961 with a histologically proved carcinoma of the bronchus and cerebral metastases. Three days after inoculation with Langat virus he became febrile, his central nervous symptoms were worse, and he became comatose. On the thirteenth day he was improving and spoke a few words. However, he then developed bronchopneumonia and died on the seventeenth day. Necropsy revealed a large cyst full of fluid necrotic material in the mid-brain. Histologically the cyst was lined by secondary carcinoma and there was no evidence of encephalitis. It seemed possible that the virus had caused destruction of cells in this secondary tumour, and that the associated oedema could have induced the coma (see also Virological Findings).

\section{Haematological Findings in the Leukaemic Group}

Of the 10 patients treated three had chronic lymphocytic leukaemia and seven had various forms of acute leukaemia. All except one (Case 3) had at some period received corticosteroids and chemotherapy. All but one of these had become refractory to such treatment and were in clinical and haematological relapse at the time of virus inoculation. This one patient (Case 8), first seen in the terminal stage of chronic lymphocytic leukaemia, was initially treated with chlorambucil, and the haematological changes observed could have been due to the drug, the virus, or both.

Total Leucocyte Count.-Eight of the patients, including six of those with acute leukaemia and Case 8 , showed a significant fall in total count following infection (Table I). The remaining two patients (Cases 7 and 10) showed falls in total leucocyte count in relation to the viraemia, but these were not statistically acceptable $(P>10 \%)$. The lowest counts, which ranged from 4 to $70 \%$ of the pre-inoculation count (mean $27 \%$ ), were observed 9 to 34 days after inoculation (mean 17 days). Though the most impressive changes were observed in patients with high pre-inoculation leucocyte counts (Figs. 1 and 3), analysis showed no correlation between pre-inoculation count and the lowest post-inoculation count $(P>10 \%)$. The fall in leucocyte count was always transient, and the count began to rise 4 to 11 days after it had reached its lowest level (mean 4.5 days). Where a fall in total leucocyte count was observed there was a proportionate fall in absolute numbers of all leucocyte types circulating at the time of inoculation (Fig. 2), and there was no evidence that the predominance of any cell type determined the degree of subsequent fall in leucocyte count. There were no consistent changes in cell morphology at any stage.

Relation of Leucocyte Changes to Viraemia and Development of Antibodies.-Where leucocyte changes occurred there was a close association between viraemia and fall in leucocyte count. Analysis of the pooled data from the leukaemic and the nonleukaemic groups showed a close correlation between the time of lowest observed count and the last day of viraemia (the difference in days was not significantly different from zero). The subsequent rises in leucocyte counts seemed to be associated with cessation of viraemia and the appearance of circulating antibodies. The characteristic relationship between leucocyte count, viraemia, and antibodies is illustrated in Figs. 1-4.

\section{Haematological Findings in the Malignant (Non-leukaemic) Group}

In this group only 5 out of 18 patients showed a significant fall in total leucocyte count (Table II), as compared with the 8 out of 10 in the leukaemic group. The pattern of fall was essentially the same as that observed in the leukaemic group (Fig. 4). The lowest counts, which ranged from 42 to $78 \%$ of the pre-inoculation level (mean 59\%), were found 2 to 24

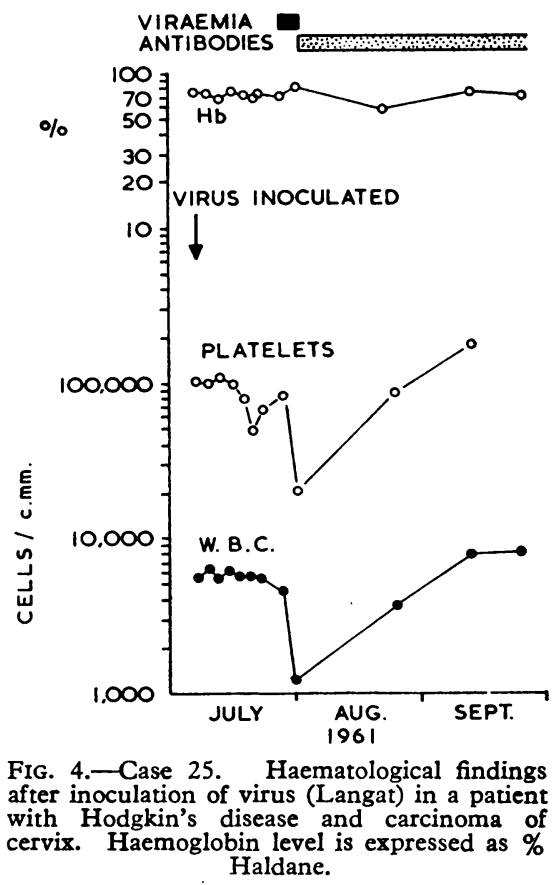

\begin{tabular}{|c|c|c|c|c|c|c|c|c|c|c|}
\hline \multirow{2}{*}{$\begin{array}{l}\text { Case } \\
\text { No. }\end{array}$} & \multirow{2}{*}{ Sex } & \multirow{2}{*}{ Age } & \multirow{2}{*}{ Type of Leukaemia } & \multicolumn{2}{|c|}{ Inoculation } & \multirow{2}{*}{$\begin{array}{l}\text { Viraemia } \\
\text { Detected }\end{array}$} & \multirow{2}{*}{$\begin{array}{l}\text { Significant } \\
\text { Leucocyte } \\
\text { Fall (P) }\end{array}$} & \multirow{2}{*}{$\begin{array}{l}\text { Fall Due } \\
\text { to Other } \\
\text { Treatment }\end{array}$} & \multirow{2}{*}{$\begin{array}{c}\text { Clinical } \\
\text { Improve- } \\
\text { ment }\end{array}$} & \multirow{2}{*}{$\begin{array}{l}\text { Length } \\
\text { of } \\
\text { Survival }\end{array}$} \\
\hline & & & & Date & Route & & & & & \\
\hline $\begin{array}{r}1 \\
2 \\
3 \\
4 \\
5 \\
6 \\
7 \\
8 \\
9 \\
10\end{array}$ & $\begin{array}{c}\text { M } \\
\mathrm{M} \\
\mathrm{F} \\
\mathrm{M} \\
\mathrm{M} \\
\mathrm{F} \\
\mathrm{M} \\
\mathrm{F} \\
\mathrm{M} \\
\mathrm{F}\end{array}$ & $\begin{array}{l}4 \\
61 \\
67 \\
45 \\
37 \\
55 \\
49 \\
70 \\
64 \\
69\end{array}$ & $\begin{array}{l}\text { Acute blast cell } \\
\text { \#"\# \# } \\
\text { Erythroid " } \\
\text { Acute" blast cell on chronic myeloid } \\
\text { Chronic lymphocytic } \\
\text { \#" \# } \\
\text { Acute }\end{array}$ & $\begin{array}{l}1 / 3 / 61 \\
11 / 7 / 61 \\
30 / 5 / 62 \\
2911 / 61 \\
21 / 3 / 62 \\
111 / 1 / 16 \\
16 / 1 / 61 \\
7 / 21 / 62 \\
11 / 10 / 61 \\
20 / 12 / 61\end{array}$ & $\begin{array}{l}\text { SC } \\
\text { ", } \\
\# " \\
\# " \\
\text { ", } \\
\text { ", }\end{array}$ & $\begin{array}{l}+ \\
+ \\
+ \\
+ \\
+ \\
+ \\
+ \\
+ \\
+ \\
+\end{array}$ & $\begin{array}{l}+(<0.1 \%) \\
+(<1 \%) \\
+(<2 \%) \\
+(<2 \%) \\
+(<5 \%) \\
+(<1 \%) \\
0(<0.1 \%) \\
+(<2 \%) \\
+(<2 \%)\end{array}$ & 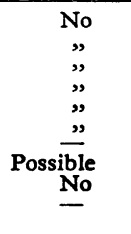 & $\begin{array}{l}\text { No } \\
\text { Y"es } \\
\text { No } \\
\text { Yes } \\
\text { No } \\
\text { "” } \\
\text { " }\end{array}$ & $\begin{array}{l}2 \text { months } \\
20 \text { days } \\
16 \text { J' } \\
11 \text { year } \\
1 \frac{1}{2} \text { months } \\
25 \text { days } \\
17 \text { months } \\
11 \text { month } \\
23 \text { days } \\
3 \frac{1}{2} \text { months }\end{array}$ \\
\hline
\end{tabular}


days after inoculation (mean 12 days), and occurred towards the end of the viraemic phase. The pre-inoculation leucocyte counts in these five patients ranged from 5,600 to $17,000 / \mathrm{c} . \mathrm{mm}$. (mean 9,400), but there was no correlation between preinoculation count and degree of fall, and all circulating cell types were equally reduced. Four of the remaining 13 patients had falls in total leucocyte count during the viraemic phase, but these were not statistically acceptable $(P>10 \%)$. Of the remaining nine patients without apparent change four did not have detectable viraemia.

As in the leukaemic group, haemoglobin trends were unaltered and no morphological abnormality of red cells, leucocytes, or platelets was observed. Three of the five patients in this group showing a significant leucocyte fall had an associated fall in platelet count (Fig. 4).

\section{Other Laboratory Findings}

No significant changes were seen in the pre- and postinfection plasma protein studies in any case, or in the E.E.G.s and E.C.G.s in those cases which could be studied.

\section{Cytological Findings}

Necropsy material was available from six patients who died during the viraemic phase (four leukaemic, two bronchial carcinoma) and from six patients who survived for 17 to 311 days after inoculation. In none of these patients, apart from the two with disturbance of the central nervous system (Burston et al., 1966), were any histological changes observed that could be attributed to virus. One other patient (Case 15), who developed a transverse myelitis, probably unattributable to the virus inoculation, is also discussed by those authors.

In one patient (Case 18) with bronchial carcinoma and multiple skin metastases secondary nodules were biopsied before inoculation, during viraemia ( 7 th day), and after the end of viraemia at 14 and 21 days. Minimal and identical degenerative changes (pyknosis, nuclear disintegration, and necrosis) were found in pre- and post-inoculation tissues. For various reasons serial marrow samples were obtained from only a few patients. So far no morphological changes attributable to virus have been seen. Serial marrow chromosome studies were carried out on one patient in this series (Case 18). It will be seen (Table III) that the first post-inoculation sample showed a complete disorganization of chromosomal pattern with, in the later post-inoculation sample, partial reversion to normality. The detailed chromosome findings in this patient and in a subsequent series will be the subject of a further report.

\section{Virological Findings in Infections with Langat Virus}

\section{Doses and Infections}

Twenty-four patients were given subcutaneous doses of 2,000-500,000 mouse ICLD I $_{50}$ of the seventh mouse-passage of the TP-21 strain of Langat virus. All except three of these (Cases 13, 16, and 23) subsequently had viraemia. Case 13 had virus in various organs at necropsy (see Table V). Case 16 had unexplained pre-existing antibody of all three types, but showed significant antibody increases. Case 23 developed antibodies. There was therefore probably low and transient viraemia in these patients. One patient, a West Indian (Case 24), was given $500,000 \mathrm{ICLD}_{50}$ intravenously but failed to show evidence of infection. She had, however, pre-existing antibody to a number of group B viruses. Two patients, mentioned in the introduction but not included in the series, were given 25 million $\mathrm{ICLD}_{50}$ of the same virus orally, but subsequently showed no evidence of infection. Monkeys have been successfully infected in this way, perhaps through mouth lesions (O’Reilly et al., 1965).

Because of the occurrence of encephalitis in two patients, less neuropathogenic strains of Langat virus were sought by plaque-passage in chick-embryo-cell cultures (Begum, 1963). Three patients (Cases 17, 19, and 21) were given 84,000 ICLD $_{50}$ of the fourth plaque-passage (after one or two subsequent mouse-passages) and all had viraemia. One patient (excluded from this series) given $13,000 \mathrm{ICLD}_{50}$ of the fifth plaquepassage, however, showed no evidence of infection.

TABLE II.-Malignant (non-leukaemic) Group-Effect of Treatment

\begin{tabular}{|c|c|c|c|c|c|c|c|c|c|}
\hline \multirow{2}{*}{$\begin{array}{l}\text { Case } \\
\text { No. }\end{array}$} & \multirow{2}{*}{ Sex } & \multirow{2}{*}{ Age } & \multirow{2}{*}{ Diagnosis } & \multicolumn{2}{|c|}{ Inoculation } & \multirow{2}{*}{$\begin{array}{l}\text { Viraemia } \\
\text { Detected }\end{array}$} & \multirow{2}{*}{$\begin{array}{l}\text { Significant } \\
\text { Leocucyte } \\
\text { Fall (P) }\end{array}$} & \multirow{2}{*}{$\begin{array}{c}\text { Clinical } \\
\text { Improve- }\end{array}$} & \multirow{2}{*}{$\begin{array}{l}\text { Length } \\
\text { of } \\
\text { Survival }\end{array}$} \\
\hline & & & & Date & Route & & & & \\
\hline 11 & $\mathbf{M}$ & 54 & Ca. bronchus & $\begin{array}{l}7 / 7 / 61 \\
7 / 7 / 61\end{array}$ & SC & $\begin{array}{l}+ \\
+\end{array}$ & $+(\stackrel{0}{<2 \%)}$ & No & 9 days \\
\hline 12 & M & 59 & ” & $\left\{\begin{array}{l}\text { K.F.D. } \\
29 / 11 / 61\end{array}\right.$ & ” & & $+(<2 \%)$ & Yes & \\
\hline 13 & $\begin{array}{l}M \\
M\end{array}$ & $\begin{array}{l}60 \\
65\end{array}$ & " & $\begin{array}{r}3 / 10 / 61 \\
25 / 10 / 61\end{array}$ & $"$ & $\frac{1}{t}$ & $0^{0}$ & No & 17 days \\
\hline 15 & $\mathrm{~F}$ & 56 & $", \quad "$ & $6 / 12 / 61$ & $"$ & + & $\stackrel{0}{0}$ & Yes & $2 \frac{1}{2}$ months \\
\hline $\begin{array}{l}16 \\
17\end{array}$ & $\stackrel{M}{M}$ & $\begin{array}{l}69 \\
54\end{array}$ & " " & $\begin{array}{l}3 / 1 / 02 \\
10 / 7 / 63\end{array}$ & ”, & $\overline{+}$ & $+(<1 \%)$ & No & $\frac{1}{\frac{1}{2}} \quad 川$ \\
\hline $\begin{array}{l}18 \\
19\end{array}$ & $M$ & $\begin{array}{l}59 \\
68\end{array}$ & ", ", & $\begin{array}{l}20 / 5 / 64 \\
10 / 7 / 63\end{array}$ & ", & + & $+(\underset{0}{<1 \%)}$ & $\begin{array}{l}\text { Doubtful } \\
\text { No }\end{array}$ & $26^{2}$ days" \\
\hline & & & 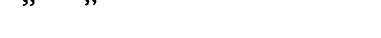 & $\int 26 / 4 / 61$ & " & + & 0 & Doubtful & 8 months \\
\hline 20 & $M$ & 54 & $" \quad "$ & $\left\{\begin{array}{l}\text { K.F. } \\
15 / 11 / 61\end{array}\right.$ & & + & & & \\
\hline 21 & F & 59 & $\begin{array}{l}\text { Squamous-cell carcinoma (primary } \\
\text { site unknown) }\end{array}$ & $1 / 1 / 64$ & ”, & + & 0 & Yes & $3 \frac{1}{2}$ \\
\hline $\begin{array}{l}22 \\
23 \\
24 \\
25\end{array}$ & $\begin{array}{c}M \\
M \\
F \\
F\end{array}$ & $\begin{array}{l}44 \\
62 \\
41 \\
72\end{array}$ & $\begin{array}{l}\text { Astrocytoma } \\
\text { Melanoma } \\
\text { Hodgkin's disease. Ca. cervix }\end{array}$ & $\begin{array}{l}26 / 4 / 61 \\
11 / 10 / 61 \\
28 / 6 / 61 \\
7 / 7 / 61\end{array}$ & $\begin{array}{l}\text { "’ } \\
\text { IV̌ } \\
\text { SC }\end{array}$ & $\begin{array}{l}+ \\
\overline{+} \\
+\end{array}$ & 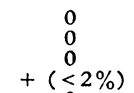 & $\begin{array}{c}\text { No } \\
\text { ” }\end{array}$ & $\begin{array}{l}4 \frac{1}{2} \quad " \\
2 \frac{1}{2} \text { year" } \\
3 \text { year } \\
3 \text { months }\end{array}$ \\
\hline $\begin{array}{l}26 \\
27 \\
28\end{array}$ & $\stackrel{\mathrm{F}}{\mathrm{M}}$ & $\begin{array}{l}68 \\
67 \\
41\end{array}$ & $\begin{array}{l}\text { Ca. breast. Lymphosarcoma } \\
\text { Mycosis fungoides } \\
\text { Myelomatosis }\end{array}$ & $\begin{array}{l}30 / 11 / 60 \\
25 / 10 / 61 \\
14 / 12 / 63\end{array}$ & ”, & $\begin{array}{l}+ \\
+ \\
+\end{array}$ & $+(\underset{0}{0} 1 \%)$ & $\begin{array}{c}\text { Yes } \\
\text { No } \\
\text { Doubtful }\end{array}$ & $\begin{array}{l}11 \\
6 \\
\text { Alive } "\end{array}$ \\
\hline
\end{tabular}

TABLE III.-Marrow Chromosome Findings in Case 18

\begin{tabular}{|c|c|c|c|c|c|c|c|c|c|c|}
\hline \multicolumn{2}{|r|}{ Sample Time } & \multicolumn{6}{|c|}{ Modal Number (\%) } & \multirow{2}{*}{$\begin{array}{c}\text { Total } \\
\text { Cells } \\
\text { Counted }\end{array}$} & \multirow{2}{*}{$\begin{array}{l}\text { Polyploids } \\
\text { Seen While } \\
\text { Counting }\end{array}$} & \multirow{2}{*}{$\begin{array}{c}\text { Other } \\
\text { Dividing } \\
\text { Cells Seen } \\
\text { While } \\
\text { Counting }\end{array}$} \\
\hline $\begin{array}{l}\text { In Relation } \\
\text { to } \\
\text { Inoculation }\end{array}$ & In Relation to Viraemia & $<43$ & 43 & 44 & 45 & 46 & 47 & & & \\
\hline $\begin{array}{l}5 \text { days before } \\
14 \text { " after* } \\
21 \% \text { aftert }\end{array}$ & $\begin{array}{l}24 \text { hours after end of viraemia } \\
8 \text { days " " " " }\end{array}$ & $\begin{array}{l}0 \\
0 \\
0\end{array}$ & $\begin{array}{l}0 \\
3 \\
0\end{array}$ & $\begin{array}{r}0 \\
13 \\
0\end{array}$ & $\begin{array}{r}0 \\
70 \\
28\end{array}$ & $\begin{array}{r}100 \\
14 \\
70\end{array}$ & $\begin{array}{l}0 \\
0 \\
2\end{array}$ & $\begin{array}{l}34 \\
53 \\
50\end{array}$ & $\begin{array}{r}14 \\
20 \\
175\end{array}$ & $\begin{array}{l}172 \\
144 \\
182\end{array}$ \\
\hline
\end{tabular}

* Analysis of 27 cells showed that the majority of abnormal cells appeared to lack chromosomes in groups IV and V and to have extra chromosomes in groups III and VII.
t Analysis of 21 cells showed that though some abnormal cells had a pattern similar to those in the 14-day sample, others had a variety of individual abnormalities. In both samples all cells with a normal modal number analysed appeared normal. 


\section{Viraemia}

The essential features in 23 patients ( 21 given TP-21 and two given fourth plaque-passage TP-77) who survived long enough are shown in Table IV. Viraemia started earlier, lasted longer, and was of a higher average titre in the leukaemic than in the non-leukaemic patients. In the latter group a patient with Hodgkin's disease (Case 25) did not start viraemia until the nineteenth post-inoculation day and continued at a low level patients developed H.I. antibody after the fourth week. Only five out of 13 developed titres over $1 / 20$ at any time, and two patients who developed neutralizing antibody had no detectable H.I. antibody for at least 20 weeks. In the leukaemic group only $14 \%$ (one out of seven) had detectable antibody by the twenty-first day, $40 \%$ (two out of five) by the twenty-eighth day, but $100 \%$ by the forty-second day. Four out of five had titres over $1 / 20$. There was a general tendency for the titres to fall with time.

TABLE IV.-Viraemia Characteristics

\begin{tabular}{|c|c|c|c|c|c|c|c|c|c|c|c|c|}
\hline & & \multicolumn{3}{|c|}{ Earliest Day } & \multicolumn{3}{|c|}{ Latest Day } & \multicolumn{3}{|c|}{ Duration } & \multicolumn{2}{|c|}{ Maximum Titre } \\
\hline & & Mean & Median & Range & Mean & Median & Range & Mean & Median & Range & $<1 \log$ & $>1 \log$ \\
\hline $\begin{array}{l}\text { Leukaemia } \\
\text { Others } . .\end{array}$ & 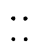 & $\begin{array}{l}6 \cdot 7 \\
8 \cdot 1\end{array}$ & $\begin{array}{l}8 \\
7\end{array}$ & $\begin{array}{l}2-12 \\
2-19\end{array}$ & $\begin{array}{l}14 \cdot 0 \\
13 \cdot 2\end{array}$ & $\begin{array}{l}14 \\
12\end{array}$ & $\begin{array}{l}9-21 \\
6-32\end{array}$ & $\begin{array}{l}9 \cdot 0 \\
6 \cdot 1\end{array}$ & $\begin{array}{l}8 \\
5\end{array}$ & $\begin{array}{l}3-15 \\
1-14\end{array}$ & $\begin{array}{r}4 \\
-\quad 10\end{array}$ & $\begin{array}{l}5(56 \%) \\
4(29 \%)\end{array}$ \\
\hline
\end{tabular}

until the thirty-second day. In another patient (Case 26), with lymphosarcoma and breast carcinoma, viraemia was detected only on the nineteenth day, there having been none up to the twelfth day.

\section{Antibody Responses}

Of the 20 patients in both groups who lived long enough 13 developed detectable levels of all three types of antibody (neutralizing, haemagglutinin-inhibiting (H.I.), complementfixing (C.F.)) ; of the remaining seven five developed only detectable neutralizing antibody within the observation period $(19,25,29,63$, and 173 days), one developed only neutralizing and H.I. antibody within 99 days, and one only neutralizing and C.F. antibody in 20 days. There was a general tendency for neutralizing antibody to be detected first: 12 of the 20 developed neutralizing antibody at least a week earlier than H.I. or C.F. antibody. Antibody of one or more types was detectable in 10 out of 20 patients by three weeks after infection. Three had antibody earlier (two weeks after infection) and the remainder later (after four or five weeks). Two of the patients with early antibody had high neutralizing and H.I. titres but no C.F. antibody on the fourteenth post-inoculation day: these were the two patients with the highest viraemia titres (300 and 1,600 mouse ICLD $_{50} / 0.03 \mathrm{ml}$.); apart from both having carcinoma of the lung, they had no other notable common characteristics.

Neutralizing Antibody.-Apart from the two patients mentioned above there was no significant difference in the time of appearance of neutralizing antibody. By 21 days after infection $73 \%$ (8 out of 11$)^{1}$ of non-leukaemics and $63 \%$ ( 5 out of 8 ) of leukaemics had antibody; by 28 days the corresponding figures were $86 \%(12$ out of 14$)$ and $84 \%$ ( 6 out of 7 ); and by 42 days all patients successfully infected had developed neutralizing antibody. After 28 days the neutralizing indices of the leukaemic group tended to be higher than in the non-leukaemic group, probably reflecting the greater viraemia in the former. After five to six weeks the log geometric mean indices were 2.5 and 2.0 respectively, and after seven to eight weeks 3.3 and 2.3 respectively. In the few patients who survived long enough the neutralizing indices remained near the highest level for up to 496 days, but a few patients-for example, Case 20, see below-had only transient low indices.

Haemagglutinin-inhibiting Antibody.-H.I. antibody appeared earlier in the non-leukaemic group, but higher and more consistent titres were reached in the leukaemic group. In the nonleukaemic group two patients had high titres on the fourteenth day, $50 \%$ ( 5 out of 10 ) had antibody by the twenty-first day, and $54 \%$ ( 7 out of 13 ) by the twenty-eighth day. Three further

\footnotetext{
1 These ratios are based on the number of patients on whom tests were
} made within a day or two of the stated day after infection.
Complement-fixing Antibody.-C.F. antibody tended to be detectable earlier in the leukaemic group, in whom higher and more consistent titres were again observed. Two leukaemic patients had detectable antibody by the twenty-first day, while the earliest in non-leukaemic patients was the twenty-sixth day. By the twenty-eighth day the respective proportions were $38 \%$ ( 3 out of 8 ) and $14 \%$ ( 2 out of 14). By five to six weeks the geometric mean titre was about $1 / 40$ in the leukaemic group but only about $1 / 12$ in the non-leukaemic group. By six weeks all the leukaemic patients had developed C.F. antibody, but four of the non-leukaemic patients failed to attain detectable levels after nine weeks or longer (Cases 12, 20, 23, and 28). The C.F. antibody was measured by two methods with broadly similar results, though the serum-dilution technique made changes more readily interpretable.

Cerebrospinal Fluids.-Simultaneous C.S.F. and serum samples were obtained from 15 patients on a total of 18 occasions, and they were compared for antibody content. Of 16 samples where neutralizing antibody was present in the serum antibody was present in the C.S.F. in seven at similar titres; in one case the log neutralizing index of serum was 3.5 and that of the C.S.F. 1.3. Of nine samples where there was serum H.I. antibody only two had H.I. antibody in the C.S.F. ; and of five where there was serum C.F. antibody only one had detectable C.F. antibody in the C.S.F. The presence or absence of C.S.F. antibody was not correlated with type of disease (leukaemia or not) or the titre of serum antibody. There was a general tendency for neutralizing antibody to appear in C.S.F. with the passage of time, but the numbers were too small to establish this: samples collected up to the twenty-first day had serum but not C.S.F. antibody, 9 out of 12 samples taken 22-23 days after infection had serum but not C.S.F. antibody, but samples taken later (43 and 51 days) had C.S.F. antibody. Tumour involvement of the central nervous system might have been responsible for antibody leakage into the C.S.F., but it was difficult to be certain which patients, especially leukaemics, did not have small tumour deposits in the central nervous system. With these reservations three out of five patients with tumour lesions of the central nervous system had C.S.F. antibody compared with one out of eight without. A combination of tumour involvement and time therefore appear to be possible factors.

\section{Post-mortem Tissues}

The results in tissues from 11 patients examined are shown in Table V. In one patient (Case 11) who died during viraemia, though virus was generally distributed, there was 1,000 times more in the secondary tumour than elsewhere. In Case 13 virus was found in a variety of tissues, including brain and tumour, though viraemia had not been detected. In three patients whose viraemia had ceased and who had significant 
TAble V.-Virus in the Post-mortem Tissues of Patients Infected with Langat Virus

\begin{tabular}{|c|c|c|c|c|c|c|c|c|c|c|c|}
\hline Case No.: & $2(L)$ & $5(L)$ & $6(\mathrm{~L})$ & $8(L)$ & $9(\mathrm{~L})$ & 11 & 13 & 14 & 16 & 18 & 19 \\
\hline Day of Death: & 20 & 44 & 25 & 29 & 22 & 9 & 17 & 25 & 73 & 26 & 12 \\
\hline $\begin{array}{l}\text { Antibody } \\
\quad \text { at or } \\
\text { near death }\end{array}\left\{\begin{array}{l}\text { Neut.: } \\
\text { H.I.: } \\
\text { C.F.: }\end{array}\right.$ & $\frac{1 \cdot 8}{4}$ & $\begin{array}{l}3 \cdot 3 \\
40 \\
16\end{array}$ & $\begin{array}{l}2 \cdot 0 \\
-\end{array}$ & $\begin{array}{l}3 \cdot 2 \\
-\end{array}$ & $\begin{array}{l}\bar{z} \\
\bar{z}\end{array}$ & $\begin{array}{l}\bar{z} \\
\overline{-}\end{array}$ & $\begin{array}{l}\bar{z} \\
\overline{-}\end{array}$ & $\begin{array}{l}2 \cdot 4 \\
-\end{array}$ & $\begin{array}{l}2 \cdot 4 t \\
10 \\
64\end{array}$ & $\begin{array}{l}2 \cdot 8 \\
80^{-}\end{array}$ & $\bar{z}$ \\
\hline Last day of viraemia: & 14 & 12 & 12 & 16 & 22 & 9 & Nil & 9 & $\mathrm{Nil}$ & 12 & 12 \\
\hline 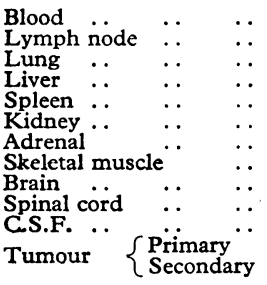 & $\begin{array}{l}\bar{z} \\
\bar{z} \\
\bar{z} \\
\overline{-} \\
\overline{-}\end{array}$ & $\begin{array}{l}\bar{z} \\
\bar{z} \\
\bar{z} \\
\bar{z} \\
\overline{-}\end{array}$ & $\begin{array}{l}\overline{-} \\
\bar{z} \\
\overline{-} \\
+\end{array}$ & $\begin{array}{l}\bar{z} \\
\bar{z} \\
\overline{-} \\
\overline{+} \\
\overline{1} \cdot 1 \\
0.7\end{array}$ & $\begin{array}{l} \pm^{*} \\
\pm \\
- \\
+ \\
+ \\
- \\
-\end{array}$ & $\begin{array}{l}+ \\
+ \\
+ \\
+ \\
+ \\
- \\
- \\
- \\
+ \\
+ \\
3.1\end{array}$ & $\begin{array}{l}- \\
1.5 \\
1.1 \\
+ \\
- \\
1.1 \\
1.5\end{array}$ & $\begin{array}{l}- \\
\bar{z} \\
\pm \\
\pm \\
\overline{+} \\
\bar{z} \\
\overline{+}\end{array}$ & $\begin{array}{l}- \\
- \\
- \\
- \\
- \\
-\end{array}$ & $\begin{array}{l}- \\
\overline{-} \\
- \\
= \\
= \\
=\end{array}$ & $\begin{array}{l}\bar{z} \\
\bar{z} \\
\overline{-} \\
\overline{-} \\
\overline{-}\end{array}$ \\
\hline
\end{tabular}

$+=$ Titre $<0.5 \log$ mouse $\mathrm{LD}_{50} / 0.03 \mathrm{ml}$. Titres expressed as $\log$ mouse $\mathrm{LD}_{50} / 0.03 \mathrm{ml}$. L=Leukaemia.

† Pre-infection antibody: neutralizing 1.2, H.I., 10, C.F., 64.

neutralizing antibody circulating virus was detected in the tissues: in the central nervous system of two, in the secondary tumour of one, and also in the spleen and adrenal gland. Virus was not detected in the patients dying 44 and 73 days after infection.

\section{Virological Findings in Infections with Kyasanur Forest Disease Virus}

Three patients were infected: Case 3 was given 7,000 mouse ICLD $_{50}$, and Cases 12 and 20, who had previously (143 and 173 days respectively) been infected with Langat virus, were given 14 and $85,000 \mathrm{ICLD}_{50}$ respectively. Prior to infection the Langat antibody pictures of these two were as follows: Case 12 had had only a transient neutralizing antibody response and had no detectable antibody when reinfected ; Case 20, log neutralizing index 3.3, H.I. 1/10, C.F. $1 / 4$.

Viraemia.-Case 3 had viraemia from the 5 th to the 17 th post-inoculation day, with a maximum titre of 10 million $\mathrm{ICLD}_{50} / 0.03 \mathrm{ml}$. and titres over 10 million $\mathrm{ICLD}_{50} / 0.03 \mathrm{ml}$. from the 7 th to the 10 th day. Case 12 had viraemia from the 5 th to the 14 th day, which never exceeded 500 ICLD $_{50} / 0.03$ $\mathrm{ml}$. Case 20 had a trace of viraemia on the 2 nd day only. Though a very low viraemia occurred in the presence of Langat antibody (Case 20.) and much less viraemia (than in Case 3) occurred in Case 12, who had been previously infected, but was without antibody, these differences may not be very significant, as Case 3 had leukaemia, and was completely non-immune, and Case 20 received a much smaller dose than Case 12.

Antibody Response.-Case 3 was still viraemic at death and had no detectable antibody. Case 20 had shown a good, though delayed, neutralizing antibody response to his original infection with Langat virus. The brief viraemia after inoculation with Kyasanur Forest disease virus did not significantly change the titre of neutralizing antibody against Langat virus or Kyasanur Forest disease virus. However, Case 12, whose original infection with Langat virus had induced only a transient neutralizing antibody response, showed a rapid neutralizing antibody response to both viruses after circulating Kyasanur Forest disease virus. A significant increase (to log neutralizing index 1.7) had occurred by the 12th post-inoculation day and high titres were present from the 21st day, when there were also high H.I. and C.F. antibody titres.

Post-mortem Tissues.-As can be seen in Table VI, Case 3 was still viraemic and high virus titres were found in all tissues, including the central nervous system-the low titre in liver is probably attributable to the action of bile salts to which these viruses are sensitive. Though only transient viraemia had been detected 30 days earlier, virus was detected in liver and skeletal muscle of Case 20.

\section{Discussion}

There appear to be three main mechanisms whereby a virus could be oncolytic: (a) it could directly destroy neoplastic cells preferentially over normal host cells ; $(b)$ it could interfere with an oncogenic virus directly, or indirectly by inducing the formation of interferon; or (c) it could induce changes in tumour cells, so that they become antigenic and thus cause the production of antibody against themselves.

(a) In tissue cultures many lines of tumour cells such as HeLa or KB are highly susceptible to destruction by a wide range of viruses. Moore $(1949,1951)$ demonstrated some oncolytic effect on mouse sarcomas by viruses in the same tick-borne complex as Langat virus. Southam and Moore (1951, 1952) showed that other arboviruses-Ilheus, West Nine, and Bunyamwera-have some oncolytic effect on reticuloses and neoplastic disease. Remissions in human leukaemia have occasionally been observed to follow virus diseases (Dock, 1904 ; Pelner et al., 1958), and recently Wheelock and Dingle (1964) described remissions but no permanent cure in a case of myeloid leukaemia in which they administered a series of virus infections.

(b) A wide variety of neoplastic diseases of fowls and rodents are known to be caused by viruses (Southam, 1963 ; Porter, 1963 ; Andrews, 1964). Though no human neoplastic disease has been shown to have a viral aetiology, two human adenoviruses have been found to cause tumours in hamsters and mice (Huebner et al., 1963 ; Yabe et al., 1964). Malignant transformation of hamster cells has been induced by polyoma and SV40 viruses, and polyoma virus will also transform

Table VI.-Virus in Post-mortem Tissues from Patients Infected with TABLE VI.-Virus in Kyasanur Forest Disease Virus

\begin{tabular}{|c|c|c|c|c|}
\hline & Case No.: & $3(L)$ & $20^{*}$ & $12 *$ \\
\hline \multicolumn{2}{|c|}{ Day of Death: } & 16 & 32 & 55 \\
\hline \multicolumn{2}{|c|}{$\begin{array}{l}\text { Antibody } \\
\text { at or } \\
\text { near death }\end{array}\left\{\begin{array}{l}\text { Neut.: } \\
\text { H.I. } \\
\text { C.F.: }\end{array}\right.$} & 二 & $\underline{2 \cdot 6}$ & $\begin{array}{l}34 \cdot 1 \\
256 \\
256\end{array}$ \\
\hline \multicolumn{2}{|c|}{ Last day of viraemia: } & 16 & 2 & 14 \\
\hline 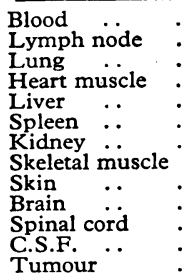 & 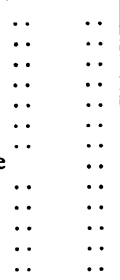 & $\begin{array}{c}+ \\
3 \cdot 3 \\
2 \cdot 7 \\
2 \cdot 7 \\
0 \cdot 7 \\
2 \cdot 5 \\
+ \\
3 \cdot 3 \\
3 \cdot 1 \\
3 \cdot 3 \\
+\end{array}$ & $\begin{array}{l}\overline{-} \\
\overline{-} \\
\pm \\
\overline{+} \\
+ \\
-\end{array}$ & $\begin{array}{l}- \\
- \\
- \\
-\end{array}$ \\
\hline
\end{tabular}

$+=$ Titre $<0.5 \log$ mouse LD $D_{50} / 0.03 \mathrm{ml}$. Titres expressed as log mouse LD $\mathrm{D}_{50} /$ $0.03 \mathrm{ml}$

$\mathrm{L}=$ Leukaemia.

- Previously infected with Langat virus.

Pre-Kyasanur Forest disease $\left\{\begin{array}{l}20 \text { neutralizing } 3 \cdot 3 \text {, H.I.- } \\ 12 \text { neutralizing } 0 \cdot 2 \text {. } \text { H.I.- } \text { C.- } . \text {.- }\end{array}\right.$ 
mouse and human cells (Shein and Enders, 1962 ; Black and Rowe, 1963 ; Habel, 1963). It thus seems possible that at least some human tumours, particularly perhaps leukaemias, are caused by viruses and that a superinfecting virus might interfere with the oncogenic virus or that interferon produced by the infection might have a similar effect. Wheelock and Dingle (1964) were working mainly on this hypothesis and were also to demonstrate interferon production in their patient. If, however, the cell becomes malignant because the viral nucleic acid has been incorporated in some way into the genome of the cell (Zilber, 1962) and the tumour then becomes virusfree, as do those caused by adenoviruses, papovaviruses, and Rous sarcoma virus (Huebner et al., 1963), interference seems unlikely to be an effective mechanism.

(c) There is, as yet, little evidence on which to discuss the third possible mechanism, but virus-induced tumours and virus-transformed cells carry virus-specific antigens (Habel, 1962) which might act in this way. The chromosomal changes seen in Case 18 suggest that such alterations may occur, and similar changes in chromosomal pattern have been reported during other infectious diseases (Nichols et al., 1962 ; Aula 1964 ; Harnden, 1964 ; Wiedemann, 1964 ; Massimo et al., 1965). When oncolysis was induced by virus infection in transplantable tumours of mice, the mice subsequently had a solid immunity to reimplantation of the same tumour (Koprowski et al., 1957 ; Lindenmann, 1963) and even to some other tumours (Lindenmann and Klein, 1965).

In none of our cases has there been any question of a patient being cured, but the results are sufficiently encouraging to justify continuation of the attempts. The patients treated were at a terminal stage of their disease, but many of those with leukaemia had a dramatic fall in white-cell count, in one patient (Case 6) associated with diminution in the size of the spleen and lymph nodes and in another (Case 3) with the regression of leukaemia skin lesions and settling of the temperature. If in these two patients the secondary infection and the thrombocytopenia could have been anticipated and controlled a significant remission might have occurred. It may be relevant that tick-borne fever in lambs, which is associated with severe leucopenia, increases their susceptibility to staphylococcal infection a hundredfold (Foggie, 1962). The haematological findings reported here suggest that the duration of virusinduced leucopenia may be limited by the development of antibodies. Therapeutic effect, particularly in leukaemia, might therefore be enhanced by suppression of antibody formation.

Of the patients with malignant disease other than leukaemia several showed possible evidence of specific effects on tumours by the virus: the disappearance of the secondary skull tumours of Case 21 ; the high virus titres in the primary tumour of Case 13 and in the secondary tumours of Cases 11 and 18 ; and the persistence of virus in the secondary tumour of Case 14. It may be significant that all of these except Case 21 had bronchial carcinomas.

The recovery of virus from the tissues of patients with circulating antibody (Cases $6,8,9$, and 14) up to 16 days after the last detectable viraemia is of interest and suggests that infections may persist in tissues for at least a limited period after the appearance of antibody. The administration of antibody to animals during the course of an infection was shown by Berge et al. (1961) to aggravate the inflammatory changes, and the presence of both antibody and virus may be necessary for their appearance. The demonstration of antibody in the C.S.F. and the perivascular distribution of the inflammatory changes in encephalitis suggest the possibility of some antigen-antibody mechanism playing a part in the development of the central nervous system disturbance. This and the possible factors in spread of antibody into the C.S.F. are briefly discussed by Burston et al. (1966).

Heath et al. (1964) reported poor H.I. antibody responses to influenza vaccination in patients with reticuloses, especially multiple myeloma, chronic lymphatic leukaemia, and Hodgkin's disease. Though the H.I. antibody response of many of our patients was poor in comparison with what we might have expected in normal individuals, there is no basis forcomparison, as natural infections are so rare. The patient with Hodgkin's disease (Case 25) developed viraemia very late (19th and 32nd post-inoculation days). She later achieved minimal antibody titres only, though 6 out of 10 non-leukaemic cases did no better. The radiotherapy given to Case 12 during his virus infection may explain his poor and transient antibody response in spite of having had viraemia. A very similar virus was inoculated later with good viraemia, caused a probable therapeutic response without radiotherapy, and he had a good antibody response. This suggests a possible method of prolonging the effect of one infection or giving repeated infections with closely related or even identical viruses.

The longer and higher viraemia, and perhaps the resultant generally higher antibody titres, in the leukaemic as opposed to other patients suggests that the virus may multiply in leucocytes and/or their precursors. This amplifies the observations and suggestions of Webb and Chatterjea (1962) and of Chatterjea et al. (1963) in cases of Kyasanur Forest disease. The same higher intensity of infection probably accounts for the occurrence of the two cases of encephalitis in leukaemia and none in other types of malignant disease-the risk may be enhanced by multiplication of virus in deposits of leukaemic cells in the central nervous system. Southam and Moore (1951) also had encephalitic complications only in leukaemics infected with Ilheus and Bunyamwera viruses.

The occurrence of encephalitis in man due to Langat virus was previously unknown-perhaps because the virus is maintained by a tick species which rarely bites man. However, though leukaemic patients may be at special risk, this argues considerable caution in the use of this virus as a live virus vaccine in man. Less neuropathogenic strains are being sought. The small number of patients in this series infected with these newer strains precludes any conclusions for the present about their safety.

\section{Summary}

The oncolytic, virological, and haematological findings are presented in 10 patients with leukaemia and 18 patients with various neoplastic disease treated with group B arboviruses (Langat and Kyasanur Forest disease).

Transient therapeutic benefit was observed in only four patients.

A considerable number of patients showed significant haematological changes. Chromosomal changes were found in the one patient studied.

Though this approach still has considerable therapeutic limitations, the present findings suggest that it merits further study.

The work carried out at St. Thomas's Hospital was made possible by grants from the Max Rayne Foundation and the Endowment Fund of St. Thomas's Hospital. The work done at the London School of Hygiene and Tropical Medicine was supported by a grant from the Tropical Medicine Research Board. We are grateful to Miss L. Pearce, Miss U. H. Glass, and Miss R. I. Kneen for their considerable help in the laboratory studies.

\section{REFERENCES}

Andrewes, C. H. (1964). Brit. med. 7., 1, 653.

Aula, P. (1964). Lancet, 1, 720.

Begum, F. (1963). Ph.D. Thesis, London.

Berge, T. O., Gleiser, C. A., Gochenour, W. S., jun., Miesse, M. L., and Tigertt, W. D. (1961). F. Immunol., 87, 509.

Black, P., and Rowe, W. P. (1963). Virology, 19, 107.

Burston, J. B., Webb, H. E., and Smith, C. E. G. (1966). To be published.

Chatteriea, J. B., Swarup, S., Pain, S. K., and Rao, R. L. (1963). Indian 7. med. Res., 51, 419.

Dock, G. (1904). Amer. f. med. Sci., 127, 563. 
Foggie, A. (1962). Symp. zool. Soc. Lond., 6, 51.

Fulton, F., and Dumbell, K. R. (1949). F. gen. Microbiol., 3, 97. Habel, K.'(1962). F. exp. Med., 115, 181.

(1963). Ann. Rev. Microbiol., 17, 167.

Harnden, D. G. (1964). Amer. J. hum. Genet., 16, 204.

Heath, R. B., Fairley, G. H., and Malpas, J. S. (1964). Brit. F. Haemat., 10, 365 .

Huebner, R. J., Rowe, W. P., Turner, H. C., and Lane, W. T. (1963). Proc. nat. Acad. Sci. (W Wash.), 50, 379.

Koprowski, H., Love, R., and Koprowska, I. (1957). Tex. Rep. Biol. Med., 15, 559.

Lindenmann, J. (1963). Proc. Soc. exp. Biol. (N.Y.), 113, 85.

and Klein, P. A. (1965). F. Immunol., 94, 461.

Massimo, L., Vianello, M. G., Dagna-Bricarelli, F., and Tortorolo, G. (1965). Brit. med. F., 2, 172.

Moore, A. E. (1949). Cancer (Philad.), 2, 525.

- (1951). Ibid., 4, 375 .

Moorhead, P. S., Nowell, P. C., Mellman, W. J., Battips, D. M., and Hungerford, D. A. (1960). Exp. Cell Res., 20, 613.

Nichols, W. W. Leven, A., Hall, B., and Ostergren, G. (1962). Heriditas (Lund.), 48, 367.

O'Reilly, K. J., Smith, C. E. G., McMahon, D. A., Wilson, A. L., and Robertson, j. M. (1965). ł. Hyg. (Lond.), 63, 213.

Pelner, L., Fowler, G. A., and Nauts, H. C. (1958). Acta med. scand., 162, Suppl. No. 338, p. 1.
Porter, G. H. (1963). Arch. intern. Med., 3, 572.

Price, W. H., Lee, R. W., Gunkel, W. F., and O'Leary, W. (1961). Amer. F. trop. Med. Hyg., 10, 403.

Sever, J. L. (1962). F. Immunol,, 88, 320.

Shah, K. V., Cole, G. A., Russ, S. B., Needy, C. L., and Buescher, E. L. (1962)., Symposium Csav. Biology of Viruses of the Tick-borne Encephalitis Complex, Praha, p. 303.

Shein, H. M., and Enders, J. F. (1962). Proc. Soc. exp. Biol. (N.Y.), 109, 495.

Smith, C. E. G. (1956). Nature (Lond.), 178, 581.

Turner, L. H., and Armitage, P. (1962). Bull. Wld Hlth Org., 27, 717 .

Smorodintsev, A. A. (1963). Proc. 7th int. Congr. trop. Med. Malar., Rio de Janeiro.

Southam, C. M. (1963). F. Pediat., 63, 138.

and Moore, A. E. (1951). Amer. F. trop. Med., 31, 724.

Thompson, W. R. (1947). Bact. Rev., 11, 115.

Webb, H. E., and Burston, J. B. (1966). Trans. roy. Soc. Med. (in press). - and Chatterjea, J. B. (1962). Brit. 7. Haemat., 8, 401.

Wheelock, E. F., and Dingle, J. H. (1964). New Engl. F. Med., 271, 64 J. Wiedemann, H.-R. (1964). Lancet, 1, 721 .

Yabe, Y., Samper, L., Bryan, E., Taylor, G., and Trentin, J. J. (1964). Science, 143, 46.,

Zilber, L. A. (1962). Acta Un. int. Cancr., 18, 127.

\title{
Observations on Infective Drug Resistance in Britain
}

\author{
H. WILLIAMS SMITH,* D.SC., PH.D., F.R.C.V.S., DIP.BACT., M.C.PATH. ; SHEILA HALLS,* B.SC.
}

Brit. med. F., 1966, 1, 266-269

Infective drug resistance is now known to be important in the spread of drug resistance among members of the Enterobacteriaceae. It has been studied extensively in Japan, where it was first discovered in 1959 ; the results have been reviewed by Watanabe (1963). By comparison little has been published in other countries. Observations on the situation in Britain have been made by Datta (1962), Anderson and Datta (1965), and Anderson and Lewis (1965). These have dealt mainly with Salmonella typhimurium.

It was felt that an impression of the importance of infective resistance as a cause of drug resistance in the Enterobacteriaceae in Britain might be obtained by assessing its incidence in Escherichia coli, since these organisms form the bulk of the enterobacteriaceal flora of the alimentary tract of man and domestic animals. The results of such a survey are reported in this paper. So are studies involving the transfer, in vitro, of resistance from non-pathogenic $E$. coli isolated from the faeces of man, calves, pigs, and fowls to some of the principal Salmonella and $E$. coli serotypes that cause disease in these species. The experiments included the use, as donors, of $E$. coli that were tetracycline-resistant only, organisms that are often found in the faeces of pigs and fowls fed diets containing tetracyclines (Smith and Crabb, 1957). The results of transferring resistance among Salmonella serotypes and from them to pathogenic serotypes of $E$. coli are also described.

\section{Methods}

\section{Transfer of Resistance}

Nutrient broth (Oxoid No. 2) in 10-ml. amounts was seeded with $0.02 \mathrm{ml}$. of a 24 -hour broth culture of the "donor" strain and $0.1 \mathrm{ml}$. of a similar culture of the "recipient" strain. The mixed culture was incubated at $37^{\circ} \mathrm{C}$. for 24 hours and centrifuged. The deposit was inoculated heavily on to a Petri plate of solid medium containing a drug to which the donor was resistant and the recipient was initially sensitive (referred to as selection medium). The plate was then incubated at $37^{\circ} \mathrm{C}$. for 24 hours and examined for colonies of the recipient strain. If any were found a few were

* Animal Health Trust, Stock, Essex. picked, purified by plating on solid medium, and a single colony was then picked into broth and the drug resistance pattern of the resulting culture determined. Controls consisting of broth that had been inoculated with the recipient culture only were always kept.

When the recipient was a Salmonella sp., deoxycholate citrate agar was used as the basal selection medium, the inoculum sometimes first being incubated in selenite $F$ medium at $37^{\circ} \mathrm{C}$. for 18 hours in the hope of suppressing the $E$. coli if they were of the kind that multiplied on deoxycholate citrate agar. When the recipient was $E$. coli, MacConkey agar was employed as the basal selection medium, except when the donor was also a strain of $E$. coli. In the latter event nutrient agar containing washed erythrocytes was used if either donor or recipient was haemolytic. When both were non-haemolytic differentiation was usually an impossible task. When the donor was streptomycin-sensitive the situation was overcome by preparing a chromosome mutant from the recipient that was streptomycin-resistant and incorporating streptomycin as an additional drug in the selection medium. On a few occasions a strain of $E$. coli naturally resistant to furazolidone only was used in a similar manner, the additional drug added to the basal selection medium in this case being furazolidone. Normally the drug employed in the selection medium was streptomycin (40-80 $\mu \mathrm{g} . / \mathrm{ml}$.$) , oxytetracycline (20-40 \mu \mathrm{g} . / \mathrm{ml}$.$) , chloramphenicol$ (20 $\mu \mathrm{g} . / \mathrm{ml}$.$) , ampicillin (20-30 \mu \mathrm{g} . / \mathrm{ml}$.), neomycin $(20 \mu \mathrm{g} . / \mathrm{ml}$.), or furazolidone $(10-20 \mu \mathrm{g} . / \mathrm{ml}$.).

\section{Sensitivity Tests}

Approximately $0.15 \mathrm{ml}$. of a 1 in 50 dilution of a 24-hour broth culture of the strain to be tested was spread evenly over the surface of a dried Petri plate of MacConkey agar, and disks containing different drugs were then applied at approximately equal distances apart. The amounts of the drugs used were $50 \mu \mathrm{g}$. of streptomycin (S), oxytetracycline (T), chlortetracycline $(\mathrm{T})$, chloramphenicol (C), and neomycin $(\mathrm{N})$, and $25 \mu \mathrm{g}$. of ampicillin $(A)$ and furazolidone $(F)$, and $150 \mu \mathrm{g}$. of sulphadimidine (Su). The plates were incubated at $37^{\circ} \mathrm{C}$. for 24 hours and read. Except in the case of sulphadimidine no difficulty was experienced in making the readings; the zones of inhibition surrounding the disks were either wide or very narrow or non-existent. All cultures that appeared to be sulphadimidine-resistant were retested on nutrient agar in which sulphonamide inhibitors had been neutralized by the addition of lysed horse 